\title{
咽頭弁移植創の治癒に関する神経組織学的研究
}

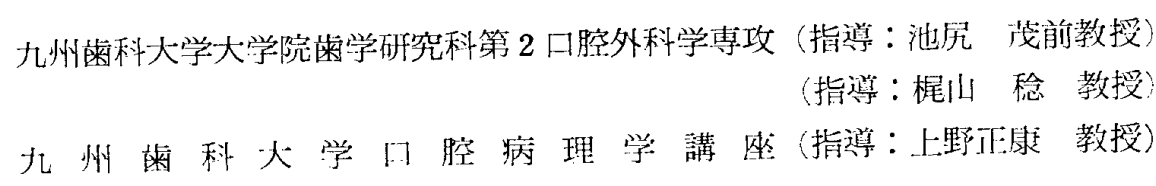

安滕紳

炤和55年 9 月 25 日受付

（本論文の要旨の一部は，昭和54年 6 月10日第39回九州蒾科学会総会において発表した）

\section{Neurohistological Study of the Healing Process of the Lesion Arising from Pharyngeal Flap Transplantation}

\author{
Shin Ando \\ Second Department of Oral Surgery (Director: Former Prof. Shigeru Ikejiri) \\ (Director: Prof. Minoru Kajiyama) \\ Department of Oral Pathology (Director: Prof. Masayasu Ueno) \\ Kyushu Dental College, Kitakyushu, Japan
}

Transplantation of the superiorly based pharyngeal flap was performed in young beagles, 99 to 110 days old, and pathohistological and neurohistological examinations were made of the healing process of the lesion. The results were as follows:

1. The epithelium at the adhesion site was extremely thin 30 days after operation but reached the normal thickness in about 180 days.

2. Infiltration of the inflammatory cells in the proper layer of the mucous membrane at the adhesion site was hardly observed in 90 days.

3. The diameter of the regenerated nerve fibers after severence increased with time and was nearly normal in 180 days.

4. Schwann cells had a great part in every instance of the regenerated nerve fibers.

5. Most of the regenerated nerve fibers running through the adhesion site regenerated and grew from the pharyngeal flap side.

6. The nerve endings were observed in the regenerated nerve fibers in 30 days.

7. The form of the nerve endings was mostly free nerve endings except that in part of the fibers it was glomerulus in 30 days, and smple ramified nerve endings with arborescence in 90 days, and glomerulus and simple ramified nerve endings with arborescence in 180 days. 
緒

言

口蓋裂患者に扑ては鼻咽腔閉鎖機能が不十分である ために，鼻咽腔の物理的な狄小化を目的とした咽頭弁移

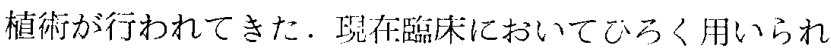
ている咽頭後臂を剥離して㰞口蓋に付符させるという方 法は, Schöenborn 18751'によって始めて行われた。

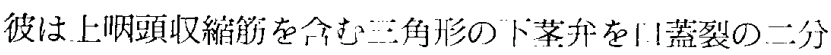

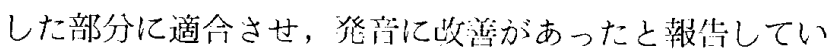

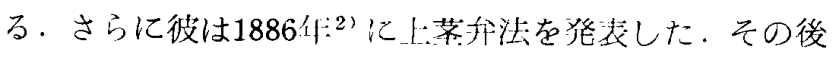
現在までに，手術法，手術による舅腔漏出の收善，手術 に件ら発音に関する研究は数多く報告されており，枚举 にいとまがない。しかし，呐頭升移植術における神経組

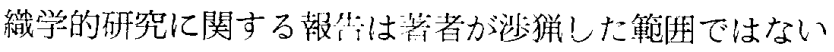
ようである。

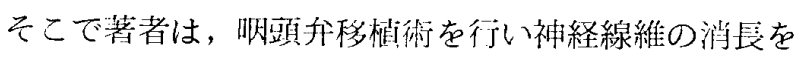
追求する目的で界験を行い, 神経組織学的検索を行って 知見を得たので報华する。

\section{実験材料及び方法}

\section{A . 车験材料}

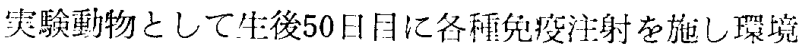

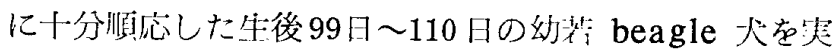
験に娂した。

\section{B . 尖験方法}

手術にあたっては，Ketaral による静脈麻酔を行っ た後, 手術相当部に $0.05 \%$ Hibitane による消毒を行 った.まず， $2 \%$ Xylocain を $2 \sim 3 \mathrm{cc}$ 注射後, 軟「1 蓋正中部を矢状面に平行に切開を加え咽頭後壁を露出し た. 咽頭後壁露出後, 闹しく $2 \%$ Xylocain $2 \mathrm{cc}$ を咽 頭後壁に追加し，同部を.上咽頭收縮筋を含む长方形の上. 萣弁となるように切開を加えた。乙の際, 弁の基底部は 環椎の高さになるようにした。切開線に沿って粘膜筋層 在含み下方より弁が十分に軟口蓋鼻腔側に付着するよう に剝離延長させた，次に先の瑱口蓋正中部切開の上縁よ り軟口蓋鼻腔側粘膜, 筋層中間部に横切開を加えた。次 に軟口蓋粘膜に平行して笳層に切開を加え, 鼻腔側粘 膜, 筋層を口蓋部より剝離して三角升を左有闻側に形成 し，上茎升を反転させ筋層を鼻腔側に反転させた。そし て軟口蓋鼻腔側の三角弁の先端を升起始部䇽風部に縫合 し, 先に作った新鮮創に弁を適合縫合し, 最後に軟口蓋 正中部を縫合して手術を終了した。

手術後, 30日，90日，180日目に筋肉内麻酔を行い放

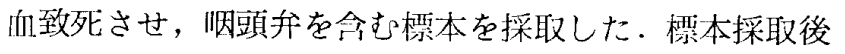

ただちに，神経湖定液にて固是し，通法に良い脱脂，脱 水を行い, paraffin 包埋後, 被経組䋞学的観察を行う

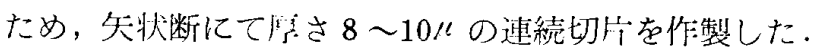

染色は hematoxylin-eosin T染色，および神経染 色を抱した。なお神経染色法は，Ungewitter(1951) 3) の疗素・硝陵銀法を Powers (1952) 4’改良を加

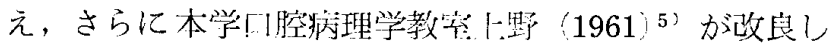
た独自の方法により行った

\section{実 験 所 見}

A. 正労組織所見

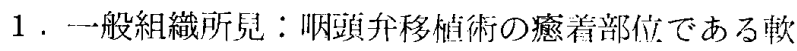
「蓋は，鼻腔側上支層，粘膜国有兽，粘膜下組織，二腔

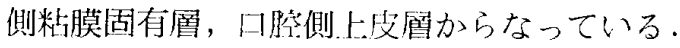

鼻腔側上㳊は多数の杯細胞を伴うほぼ一定の鸤さの多

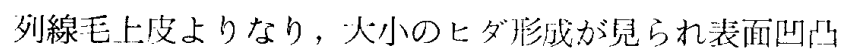

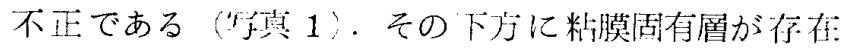
し，自管やリンパ組蟣が琹められる。さらにその下方に 粘膜下組織が存在し，その中で矩組織と腺組織が混在し てかなりの局さをなしている(写真 2)。笳凰は横紋筋 線維が筋線維束を玥成しており，その笳線維来の大きさ は大小不闰である。腺組織は, 漿液腺, 混命腺は_L没近 くに多く分布し糊液腺は粘膜下縕織全体にわたって分布

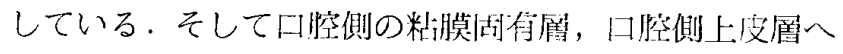

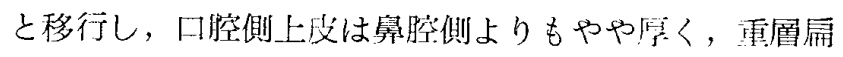
平上皮よりなっている（写真 3 ）。

咽頭弁移植手術の弁を採取する咽頭後壁は上皮層，粘 膜固有層，粘膜下組織からなっている(尌高 4 )。

上皮は軟口蓋賞腔側上发の--部之间じく，多数の杯細 胞を伴ったほぼ一定の婜さの多列線巨上文よりなり，大

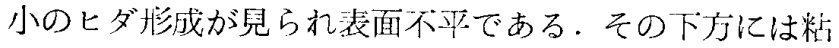
膜固有層が存在し，血管が多く冒られ，リンパ性組織に

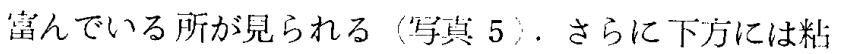
膜下組織が存在し，横紋筋線維が筋線維凁を形成してか なりの店さで筋層が見られ，その線維束の人きさは不闹 である.又それら筋線維束間には粘膜下組織上部で粘腹 腺の介在が見られる。

2. 神経組織所見：軟口蓋においては粘膜下組織勺に 大神経束が，腺組織や筋組織の間を走行し未梢に行くに 従い分岐して表層に间っている（写真6).

粘膜下組織内においては, 多くの神経束は蛇行してお り，そのまま自由終末として終っているものもあり，筋 層内に分岐された，中・小の神経杂においては，ほとん どが筋線維に沿って走行しており, 筋線維に終未を形成 
しているものも見られる．粘膜固有層に分岥された神経 束は固有層下部で縦横に走っているのが見られ，そのま ま自由終末として終っているものや，さらに小神経束に 分岐して粘膜固有層上部に向い，上皮に沿って走行して いるものと，上皮に们うように走っているものとが見ら れ(写真 7)，そのまま自由終末として終っているもの が多いが，上皮内に遊離終末を抢成しているものもあ る。

呐頭後壁においては，粘膜下組織に大神経束が走って

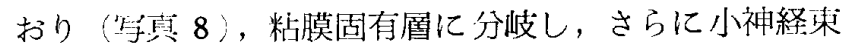
へと分岐している。

粘膜下組織老定行している神経束は筋層間の絬合織 に，抖・小の神経束となって幾分分岐し，さらに筋線維 束間にも分岥し，微細終未枝となっているのが見られる。 粘膜估有層を走っている神経束は，そこで自由終末と して終っているものが多く，上皮近くでは上皮に沿って 走行している神経線維と上皮に向うように走っているす のとが㒻られる(写真 $9 ， 10$ )。

B . 実験例所見

1. 移植後 301.1 笑験例：I

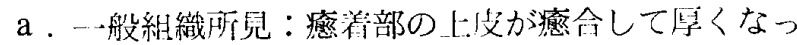
ている部分は，上皮紐胞の配列に不規則なところが見ら れる。.上皮下では炎症性細胞の浸潤が兒られ，膠原線維 の走行も一定ではなく緻密化しており，毛細血管の一部 が拡张しているのが見られる(写真11)。また分断され て膨化し変性を起ししている觔線維が散見され(写真12 さらに腺細胞の一部には萎縮が見られる。

b，神経組織所見：癒着部门おいては，粘膜下組織内 で血管付近に，片・小の神経束が多く分布しているが， それより離れた部位上比較して, 数も太さも差買は見ら れない，神経束断端ではその部分に Schwann 細胞が 增殖しており，その内側では細い神経線維が堌殖した Schwann 細胞に沿って蛇行して走行し, 中には他の神 経線維と交錯するように走っているものもあり，粘膜下゙ 組織队で自由終未として終っているものが多い 写是 13）。粘膜固有屏には神経線維の分布が非常に少なくわ ずかに見られる神経線維も単独で走行しており，そのま ま自由終末となり上没への分岐も胃られない，瘾着線上 と思える部位に分断されている筋線維には神経線維の分 布は見られないが，近接した軟口蓋の筋層において，配 列の乱れている筋線維束閒には筋線維任沿って比較的多 く神経線維束が分布し，中には筋線維をまたぐように走 行しているものもあり，筋線維内に終末を形成している のが見られる。
2 . 移植後 30 日 达験例：II

a，一般組織所見：撚着部において上皮層は菲薄で $2 ， 3$ 層の上皮層しか見られない部隹もあり，山兄もわ

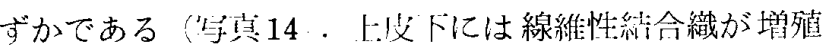
し，その走行は不規則である。 さらに呐頭後壁側では腺 紐胞の一部が破㑢され，それに隣接して軟垱化生椂の像 が見られる.又㳄口蓋側においては痖都部に近い筋線維 束が膨化しており，その走行か活れている。

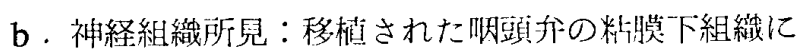
は，大・小の神経束が上没に的してほぼ平行に走行して おり，一部を除いて比較的まっすぐに走っている．蛇行 している神経束には比較的大きな神経線維が会まれてい て腺組織に近在しており，写其15それに沿って微緑 な神経線維が単独に見られるが，そのまま自由終末とし て終っている，粘膜固有層に見られる神経束は，粘膜下 組織に見られる神経束に比較して細いが，数多く見られ る、神経線維の走行はほとんど上皮に沿って比較的まっ すぐに走っておら，上皮方向への分岥は見られない，ま た，紐い神経線維が単独に縦横に走行しているのが散見 されるがすぐに自由終枺として終っている。

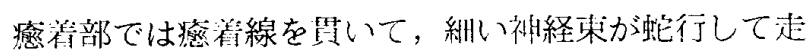
行しており，ほとんどが目由終米として終っているが， 系球状終末形態をなしている神経線維も見られる（写真 16) .

3 . 移植後90日（尖験例：III)

a .一般組織所見：些頭升の明頭後壁側において上芚 の一部が剝離されて欠損している部位があり，上皮下で は炎症性細胞の浸潤がわずかに見られ，同部の血管の桩 振が兒られる。明頭弁内の上氺にも一部火揁と上皮下に 炎症性紐胞の浸潤が恇られ，線維性結合組織の增殖も見 られるが，移植後30日に比校してその走行は規則的であ る。癒着部においては上皮の一部に菲薄な部位が胃られ るが，移植後30日に比べて再生も進んでおり，軟口蓋と の移行もなめらかである．上皮下には一部破流された り，萎縮している腺細胞が存在し，やや走行の不規則な 線維性結合組織が見られる。また䖍着部に近接した軟口 蓋の筋層では，筋線維のわずかな膨化，断裂が兒られ， その部仿の筋線維束の走行が乱れており，同部の血管が

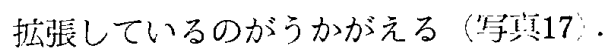

b . 神経組織所兒：㐻頭分の神経は，呐頭後壁側にお いては，血管に沿うように絒い神経線維が走行しており (写具18)，その他単独佂超っている神経線維も一樣に 細く，そのまま自由終末として終っており，正常な网頭 後壁に比べて分布も少ない，癒着部とそれに近接した部 
位においては，上皮下の腺組織の直下に療着部を貫いて 細い神経線維が比較的まっすぐに走っており（写真19）， 上皮下のリンパ組織偪富む部位の中には Schwann 細 胞に沿って，その内側在走行している微細な神経線維が 束をなして蛇行して走っている（写真20）。さらに軟口 蓋より分岐してきた神経束が切断されて，断端より再生 したと思える細い神経束が療着部まで走っており，癒着 部にて分断された軟口䓝の笳線維之腺組織の間の血管に 沿って，細い神経束が蛇行して走行しておりいずれも自 由終末として終っている(写真21)。

4. 移植後 90 日 (実験例：IV)

a.一般組織所晃：痖着部の上皮は移植後 30 日に比べ て厚く規則正しく形成されている，その下層には资症性 細胞がわずかに見られ，増殖した線維性結合組織の中に 数個の腺紐胞が見られる。㽿着部より軟口蓋側では近接 した腺細胞の破壊と萎維が見られ，軟口㥺鼻腔側の筋層 の一部で筋線維束の膨化が見られる、咽頭弁内はわずか な炎症性細胞の浸潤之呐頭後壁側の上文の一部が久損し ている事を除いて著変は見られない（写真22）.

b . 神経組織所見：呐頭升内の神経は，上皮下，粘膜

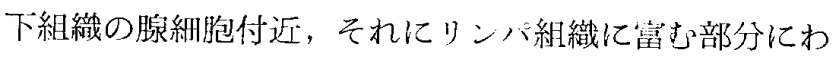
ずかに，細い神経線維が走行しているが正常な临頭後壁 に比較してその数は少ない，癒着部において切断された 神経束は，その断端において Schwann 紐胞に沿って 微細な, あるいはやや太い神経線維が蛇行しながら伸展

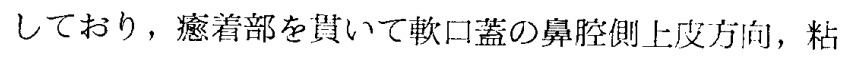
膜下組織へと分岐している(马具23)。上皮方向に分岐 された神経線維は上皮に達しないまま, 又粘膜下組織一 と分伎された神経束は腺組織間の結合組織内で自由終末 として終っているが, 咱頭升内においては, 驿純性分岐 性終末として樹枝状を呈しているのが見られる(写真 24).

5 . 移植後 180 日 (実験例：V)

a 、一般組織所見：瘾着部の上皮は一部唇くなってい る部位があるが，完全に修復されており，粘膜固有凰に も著変は見られない。粘膜下組織に扔いては筋線維束が 分断され，その走行が乱れているのが見られる(写真 25).

b. 神経組織所見：癒着部では，上专下に Schwann 細胞汇沿って走行している神経束が見られ，朋頭升内に まで分岐されており，その神経線維の太さ, 数は正労組 織と比較して差異はない(写真26). 筋線維束の走行が 乱れている部位では, 筋線維束間に, Schwann 細胞に 沿って蛇行して走行している神経束が見られ, 自由終末
として終っている(写真 27). 又微綀な神経線維が縦横 に走っており，ほとんど自由終末として終っているが， 系球状終末形態をなしているものと，単純性分岐性終末 として樹枝状を呈しているものが兒られる。

6 . 移植後 180 日 (実験例：VI)

a .一般組織所兒：療着部の上皮は完全に修復されて おり，粘膜固有層にも著変は見られない。粘膜下組織に は, 瘾着部に近い哚線維束に, 分断されている筋線維が 散見され筋線維の走行が乱れているのが見られる（写真 28) .

b . 神経組織所見：療着部において粘膜固有首に神経 線維が見られるが, 単独に走っていて, 数は少なく, 自 由終末として終っている。粘膜下組織においては, 朌線 維束間に神経線維の走行が見られ自由終末として終って いるが，正常な神経線維と比較して太さに差異はない。 又リンパ球に富志部位の中に Schwann 紐胞に沿って 蛇行して走行している神経束が兒られ，やはり自由終末 として終っている(写真29).

7 . 移植後 180 日 (実験例：VII)

a .一般組織所見：癒着部の上皮は，一部厚くなって いる部分と，剝離されている部分があるが，ほぼ完全に 修復されている。粘膜固有圆に著変注見られないが，粘 膜下組織においては，分断された筋線維が散兒され，筋 圈の一部の筋線維束に走行の乱れているとてろがある (写点 30 ).

b . 神経組織所兒：粘膜固有層には Schwann 細胞 に沿って神経線維束が蛇行して走行しており，そのまま 自由終末として終っている(写頁 31 )。粘膜下組織の筋 層において，筋線維束間に兒られる神経線維は，太さも 数も正常所見と大差ないが（写真 32 ), 分断されて散見 される觔線維近くに見られる神経線維は一様江紐くその まま粘膜下組織内で終っている。

\section{実験所見の総括}

1.一般組織所見：癒着部上皮は移植後30日ではまだ 菲薄であり，上皮細胞にも不規則なとてろが芫られ，移 植後90日，180日，と経過するにつれ，上皮層も規則正 しく厚くなっている.上皮下の炎症性細胞の浸潤は移植 後30日では著明であり，90日でほとんど見られなくなっ ている. 又, 毛細血管の一部に拡張が見られ, 線維性結 合織の増殖が起っており，その走行は移植後30日では, 不規則であるが90日では規則正しくなり，180日では90 日と贸わらない。ささらに腺細胞には一部に破壊之菱縮が 
見られるが，移植後の日数による変化はあまり兒られな い.筋線維は一部分断された筋線維が散見され，移植後 30日では筋線維の膨化，変性を起こしているのが見ら れ，90日においてもわずかな膨化がうかがえる。また近 接した筋層の一部の筂線維束の走行が各実験例に見られ るが，走行状態はいずれも乱れている.

2. 神経組織所兒：咽頭升内では各例共に，血管, 腺 組織の近くに神経線維が多く見られ, 切断された神経束 断端では Schwann 細胞が增殖しており，その内側で は細い神経線維が Schwann 細胞に沿って蛇行して走 行しているが，移植後30日では正常所見と比較して細い が，90日，180日と経過するにつれてその徍を增し太く なっている.再生した神経線維はほとんどが自由終末と 乙て終って扔り，わずかに移植後30日で系球状終末， 90 日で単純性分㞳性終末，180日で糸球状終末，単純性分 岐性終末が見られるのみである. 又上皮内に終末型を形 成している神経は兒られず，分断されている筋線維㲹も 神経線維の分布は見られなかった。しかし湶着部に近い 軟口蓋の筋㬝に扑て, 走行の乱机ている筋線維束間に は比僌的多く神経線維が走行しており，筋線維に終末を 形成しているのも見られた。

\section{考察}

本夷験の实験結果を考察するにあたり，便宣上，㐻頭 弁手術方法，一般組織所見，および神経組織所見とに分 け，それぞれを考察する。

鼻咽腔を物理的に狄小化しようとする咽頭并移植手術

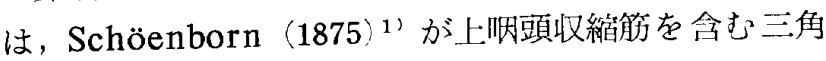
形の下䒚升を，口蓋裂の二分した部分に適合させたのが 始まりであり，さらに彼は1886年には上菜弁法を発表し た.その後, Rosenthal (1924 ${ }^{6)} ら$ 多くの人たちによ って咽頭弁移植手術の方法が発表されている。质れらに よると手術法は大きく分けて, 呐頭後壁を下方より剥離 し, 基底部を上方にする上萃弁法と, 呐頭後壁を上方上 り剝離し，基底部を下方にする下蕉弁法とがある。前者 の長所について, Moran (1951) ${ }^{7}$ は術後の出血の等理 がしやすく, 升の幅と長さが十分に取り易いと述べ, Massengill and Georgiade $(1974)^{8)}$ も乙れを支持 し, Cox and Silverstein (1961) ${ }^{91}$ は并の離断が少な いことを37例の手術結果から発表している，又永井（19 67) ${ }^{10}$ は Schöenborn-Rosenthal 法を軟回莣の正中 分割をおてなった後に，上蕉弁法を移植する方法を発表 し，ての方法だと鼻呐腔の前後径が著しく大きな場合で も，直視下で十分な長さの珚頭升が採取できると述へ
ている，一方短所については，技術的に困難であると Moran $(1951)^{7)}$ は述へ, Conway (1951) ${ }^{11}$ ， Skoog (1965) ${ }^{12)}$ は低位縫合法では瘢痕収縮により軟曰蓋が 索引されるとしている.しかし，この点については， Smith, et al. $(1963)^{13)}$ が口蓋よりやや高位から上茎 弁をとり，Owsley and Blackfield (1965 ${ }^{14}$, Owsley, et al. (1966) 15) が, 升の基底部を環椎結節の高 さに設置する上茎弁法を発表して以来解決されたようで あり，一般的汇採用され，我が国に扔いても，Isshiki， et al. (1966 16)もこの方法住隼じて満足な結果が得ら れたと述へている。これに対し下荎弁については， Padgett (1933) ${ }^{17)}$, Conway and Goulian (1960) 181は技術的には簡単であると長所を述心゙, Padgett and Stephenson (1948) ${ }^{19)}$ は十分な㕨頭組織在得ら れない. Skoog $(1965)^{12)}$ は軟口蓋の挙上障害がある. Fára, et al. $(1970)^{20}$ ', Fára $(1971)^{21}$ は出血の管 理が困難であるとその久点について指摘している. 以上 の二つの方法汇刘して, Hynes (1950 ${ }^{22}$, Sullivan (1961) ${ }^{23}$ は咽頭側壁より，升を採取する両側弁法を発 表し，そのうち Hynes $(1950)^{22}$ は，ての方法による と上咽頭収縮筋の障害がないと述へている。

今回著者の採用した眭頭升移植術の方法は, Massengill $(1974)^{8}$ の方法汇集じたもので，術後の并の退綃 も少なく，正常な治瘾過程をたどれば弁は，自然に管状 になるという，Padgett（1930１7）の報告を始めとす る, Conway $(1951)^{11}$ 'の報告と一致した。今四の著者 の採用した方法は，基底部が高位になり，鼻㖞腔が広い 時には有効であり，臨床においても採用されるべき方 法であろう。ただし, 臨床においては, レ線, fiber一 scope, 筋電図なぞを利用して, 各患者の鼻吡腔の生理 的条件を明確にして手術法を決定する必要がある。

㓣傷治癒関する報告は，世良 $(1933 ， 1934)^{24,25)}$ の口腔粘膜の創傷治瘾過程をはじめ多くの報告がなされ ている. 今回の著者の实験では，抈頭後壁部における移 植創の, 術後 30 日，90日，180日における観察を試みた のである。

粘膜上皮の治療過程について北村ら $(1968)^{26}{ }^{\prime}$ は，切 創部上皮は 3 週日頃まで肥原を走すが 4 週目に至るとほ ほ正常状態に回復することを，犬の口唇により報告して おり，迫田 $(1976)^{27}$ も大舌による実験によりてれを 確認しているが，著者の実験では，上皮は術後30日にお いてま，上皮層は菲薄で， $2 \sim 3$ 層の上皮層しか見られ ない部位もあり正常状態には回復していない。この事は 実験部位の違いによるととが創傷治瘾の正常”機転を好げ 
る因子，例えば，発声とか，暖下とかによるかも知れな いがそれについては今国の寒験では明確ではない。

粘膜下組織層については, 術後30日では線維性結合織 の畦殖が見られ，さらに炎症性細胞の浸潤も浔められ た・これが術後90日では, 線維化が進んで陳旧化し, 炎 症性細胞はほとんど胃られなくなった。

迫田 (1976 $)^{27}$ は切㓱部の粘膜下組織層について術後 15日になると，肉芽組織内，およびその周团の炎症性紐 胞の浸潤は涊めなくなり，奶若肉车組織の線維化が始ま り，その後日数を経るにしたがい陳旧化が進み，術後90 日になると舌背および舌下の粘膜下組織とほぼ同様の所 見を呈していたと報告したが，本実験では炎症性細胞の 浸潤は術後 90 日でほとんど認められなくなり，北村ら

(1968) 26)の切創部の新生肉车組織队および周囲には術 後 8 週になってほとんど炎症性細胞が消失したと述べて いる報告よりも遟い。乙れについては，本夷験部位が術 後の感染などの有無が確永しにくい事もあり, はっきり した事はいえないが, 体蕰, 食物摂取量, などから考え て感染などの偶発はなかったと思える，そこで上皮の治 癒が先人の報告と比較して遅れていた事と同様の原因で はないかと考える。

筋層の治癒過程について, 横紋筋の丽生に関しては今 井ら $(1973)^{28}$ 'は横紋筋切除後, 箭線維断端加筋形質 芽が生ずることによって行われると述べている，小沉 $(1959)^{29}$ は，家鬼横紋筋を挫隇，切断した場合再生は 3 週後に終了寸ると報告し，石井 $(1971)^{30}$ ，術後30E には接合部筋層の全体にわたって筇線維が父錯し，70日 以後は，筋線維は正常に近い幅径を有するものも多い が，不完全な筋線維が混在し走行も不整であると述べて いる．又北村ら（1968）26'は，作創後 3 週目頃加ら筋線 維の再生伸長をみとめ，8週目になると切創部筋層の全 層にわたって，再生した筋線維がみられるが，正常なも のと比べて小さく，配列状態も乱雑であると報告してい る.

著者の奏験では, 術後30日の所見では, 笳線維の膨 化, 変性が見られたが，はっきりとした再生機転は見ら れなかった．90日，180日の所見では，笳線維の幅佳は 正常組織之大差なく，その走行は不整であるのが見ら れ，乙の点では, 石井 $(1971)^{301}$, 北村ら $(1968)^{26)}$ 一致する.

Smith and Dedo (1971 $)^{31}$ は, 呐頭後壁, 側壁の 運動神経は舌佃神経の栶頭枝により支配され，これは軟 口蓋の高さで上咽頭収縮筋の側方から正中へ走行する ことを，犬の解剖と神経刺激法とから証明しており，
McCoy and Zahorsky (1972) 32) は屍体解剖により， 舌栶および迷走神経は大動脈孔を出て咽頭側壁を下降 し, 舌骨大角の約 $1 \sim 2 \mathrm{~cm}$ 高位で近心にまがり, 四頭収 縮筋の線維の走间と竝行に走り，上，中咽頭収縮筋を支 配することを碓恐している. 又軟口蓋の口蓋帆挙筋は， 舌呐神経と迷走神経の咽頭枝に支配されている。したが つて著者の実験方法では上記の神経を切断している。

末梢神経が切断された場合，その中枢側では一次変 性，未梢側では一次変性ならごに二次変性が起こること はすでに知られており，特に未梢側の神経線維の二次性 変性について，Waller が1852年に報告して以来 Waller 変性として知られている。乙の Waller 変性に関 して, Young (1942) 33', 福山 $(1958)^{34)}$ などが追求 し詳細に報告している。それらによると，Schwann 細 咆は漸次分裂增殖して Büngner 氏索を非成すると追 べている. 竹内 $(1956)^{35 \prime}$ ，松下 (1959)36) はそれぞれ

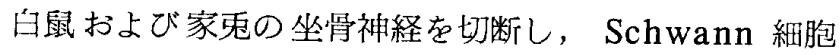
の增殖は術後 8 日〜30日にわたると報告し，迫田(19 76) 27 の大舌による実験では，術後 3 日で Schwann 細胞の增殖がおこり, 術後15日で Büngner 氏索を確恋 している. 又, 入学 $(1979)^{37}$ も もによる実験で Büngner 氏索は術後10日〜15日で形成されたと報告してい る.さらに迫田 $(1976)^{27}$ は再生された神経線維は漸時 烽を增し太くなり, 術後180日において, 切断された神 経束を構成する神経線維の径は正常所芫とほとんど変わ らないと述べている。

著者の実験では，術後30日に扑て，すでにWaller 変性をおこした後と考えられ，Büngner 氏索を確 琹することはできなかったが，明らかに堌殖している Schwann 細胞を確認することができ，その内側に再生 したと思われる微細な神経線維が確認でき，術後90日に おいてはその径が增し，術後 180 日においては正常所見 とほとんど変わらない事を確認した。

末梢神経再生に関しては今韭ら $(1971)^{28}$ 亿よると， 連結的再生と非連続的再生との $2 \supset 0$ 説がある．前者 は, 変性した神経束が Büngner 細胞索を形成し，乙れ が中枢側から牙出延長してくる軸索の誘導路となり，次 第に延び遂に終末装犆まで達するという説であり，後者 は，末梢側の軸索原線維は最初中枢側とは無関係に，新 牛: Büngner 細胞索で独自的に，自所性に形成され， そのうちで, 後に中枢側から延長再生してくる軸索と連 絡したものだけが伝導能性の軸索として完成されるとい う説である。栶䫓弁移植術において，その癒着部位の再 生神経については，軟口蓋側から再生して㸶頭手内に伸 
長した場合と，咽頭弁側から再生して軟口蓋に伸長した 場合が考えられるが, 著者の実験では, 咽頭弁側から再 生して軟口蓋に進入した神経線維を多く確羿できた。

咽頭弁移植のような有茎の粘膜移植について, 組織学 的に観察したものはなく，移植における神経再生につい ては, 内藤 $(1950)^{38)}$ の有茎皮膚移植, 山田 $(1960)^{39}$ の遊離皮膚移植, 阿部 $(1974)^{40}$ の遊離粘膜移植などの 報告が見られるがそれらによれば，再生神経は，周囲お よび基底部母床の神経線絡の断端および側方から，直接 伸長によって起とり, Schwann 細胞および血管, 結合 組織に沿って，あるいはそれらと無関係に伸長し，移植 片内の Büngner 氏索に進入するが，まれに直接移植片 内の結合織内に進入するものもあると述べている. 石井 $\left.(1971)^{30}\right)$ は再生神経線維は Büngner 氏索と関係のあ るものと，ないものとがあり，前者は移植片内に多く後 者は，接合部およびその付近に多いと報告している．著 者の実験では，再生神経はすべて Schwann 細胞と関 係して走行していた。この点については, 石井（1971）

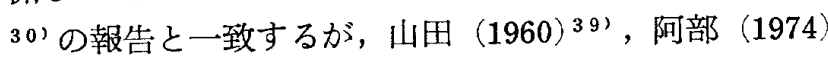
40) らの報告とは異なっていた。これについては, 山田 $(1960)^{391}$, 阿部 $(1974)^{40)} ら$ 奏験にくらべて, 著者 の㬰験である咽䫓升が厚いためではないかと考える．

再生した神経の終末に関して，知覚神経終末につい て, 内藤 $(1950)^{38)}$ は術後30日頃に上皮に遊離終末が， 又術後35日〜49日で毛根部に終末が形成されたと述べて いる. Santoni-Rugiu（1966） ${ }^{41}$ は有茎皮膚移植を家 鬼に行い，術後40日に上皮下に終末を，術後55日に毛㹕 に終末を認めている。 山田 $(1960)^{39}$ は術後 4 週〜 5 週 に乳頭内に遊離終末を認め，6週においても毛囊に輪状 終末を認めたといっている. 入学 $(1979)^{371}$ は術後45日 には表皮直下や皮下乳頭内に終末が見られたとしてい る.著者の実験では，術後30日で粘膜組織内で自由終末 が見られたが，上皮内には見られなかった。内藤 $(1950)$ 38)，山田 $(1960)^{391}$ Santoni-Rugiu $(1966)^{41 \prime}$ ，入 学 $(1979)^{37}$ 万と比較して皮膚が含まれていない事か ら，はっきりとした比較はできないが，阿部 $(1974)^{403}$ の報告でも術後25日に上皮直下に終末を認めており，ほ ぼ一致すると思われる。運動神経終末に関して, 石井 (1971 $)^{302}$ は術後30日で終末部を形成したと報告し，入 学 $(1979)^{37}$ は再生神経は術後45日に筋線維に達し, 運 動神経終末を形成していたと述べている。

著者の実験では, 術後30日にて筋線維に終末を形成し ているのが見られ，不井 $(1971)^{30}$ の報告と一致する が, 入学 $(1979)^{37)}$ の報告よりも早期である. 又,
Fára and Véle (1972) ${ }^{42)}$ は咽頭弁移植手術の患者に つて筋電図学的検索を行い，1年以内に強い電気的反 応があり，その後徐々に減少し，乙れは朌の萎縮と線維 組織への置換を示すものであると述べている. 又, 下茎 弁の方が上茎弁に比べて線維組織に変化し難く, 神経の 損傷も少なく, 高い筋放電と持続を示すと報告してい る. 他に移植後の患者についての筋電図学的報告は, 唇 弁舟転後の患者について, Smith (1960)43) は術後 6

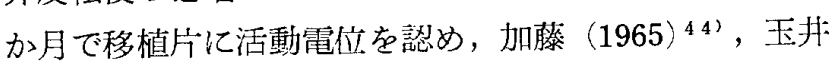
$(1970)^{45}$ は術後 2 か月で現われ，術後10〜12か月で正 常の活動電位が観察されたと報告している。これらの臨 㦿的報告は運動神経の終末形成と活動電位とは一致しな い事を示し, 咽頭弁移植後の患者の発音訓練の時期もこ の事に関連すると考えられる。

終末形態に関しては著者の実験では, 術後30日の一部 の神経線維に糸球上終末が，また術後90日には単純性分 岐性終末として樹枝状を呈したものが，術後 180 日には 系球上終末が見られるだけで, 他の神経線維はすべて自 由終末であり, 犬の咽頭後壁, 軟口蓋には単純な終末が 多かった。

\section{結 論}

著者は，生後 99日〜110日の幼若 beagle 犬に上䒝弁 法による吠頭弁移植術を行い，阁部位の治疩過程を病理 組織学的, ならびに神経組織学的に検索を行い, 次のよ うな結論を得た。

1. 癒着部上皮は術後30日においては, 甚だ菲薄であ ったが, 術後 180 日頃正常の厚さに達した。

2. 癒着部粘膜活有層内の炎症細胞浸潤は術後90日に おいてほとんど認められなくなった。

3. 切断後, 再生された神経線維は目数が増すごとに その径を増し, 術後 180 日においては, 正常所罗と巠が なかった。

4. 滧着部を貫いて走行している再生神経線維はすべ て Schwann 細胞か関与していた。

5. 臆着部を貫いて走行している再生神経線維は咽頭 弁側より再生して伯長したものが多く兒られた。

6. 再生神経線維は, 術後 30 目で終末形成が誌められ た.

7. 終末形態については, 術後 30 日に系球状終末, 90 日に単純性分岐性終太こして樹枝状を呈したもの，180 日に糸球状終末，単純性分岐性終末として樹枝状を呈し たものが，一部の神経線維に羿められたほかはすべて自 由終末であった。 
稿を終るにあたり，本研究に終始御懇切なる御指導， 御校閲を賜った，池尻茂前教授，梶山稔教授に深楞 なる感謝の意を捧げます。また，御賏篤なる御助言，御 校閲をいただきました本学口腔病理学教室上野正康教授 に満腔の謝意を㳖し，あわせて種々の御協力をいただき
ました教窒諸见，ならびに本学口腔病理学教室の皆様に 深く感謝の意を表します，本研究は，昭和52年度，53年 度, 文部省科学研究費一般研究 B (No. 248344）の一 部による。

\section{文 献}

1) Schönborn, K. : Ueber eine neue Methode der Staphylorrhaphie, Verh. Dtsch. Ges. Chir. $4: 235-239,1875$.

2 ) Schönborn, K. : Verstellung eines Falles von Staphyloplastik, Verh. Dtsch. Ges. Chir. $15: 57-62,1886$.

3 Ungewitter, L. H.: A urea silver nitrate method for fibers and nerve endings, Stain Technol. $26: 73-76,1951$.

4 ) Powers, M. M. : The staining of nerve fibers in teeth, J. Dent. Res. 31:383-392, 1952.

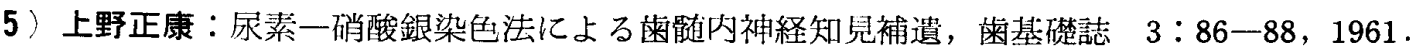

6 ) Rosenthal, W. : Zur Frage der Gaumenplastik, Zentralbl. Chir . 51 : 1621-1627, 1924.

7) Moran, R. E. : The pharyngeal flap operation as a speech aid, Plast. Reconstr. Surg. $7: 202-213,1951$.

8 Massengill, R. Jr. and Georgiade, N. : Results obtained from utilizing the new anteriorly superiorly based pharyngeal flap, Cleft Palate J. $11: 333-342,1974$.

9) Cox, J. B. and Silverstein, B. : Experiences with the posterior pharyngeal flap for correction of velopharyngeal insufficiency, Plast. Reconstr. Surg. $27: 40-48,1961$.

10）永井 缕：口唇裂・日蓋裂の手術手技について(3)，幽界展望 $30: 517-524 ， 1967$.

11) Conway, H. : Combined use of the push-back and pharyngeal flap procedures in the management of complicated cases of cleft palate, Plast. Reconstr. Surg. $7: 214-223$, 1951 .

12) Skoog, T.: The pharyngeal flap operation in cleft palate, Br. J. Plast. Surg. 18:265282,1965 .

13) Smith, J.K., Huffman, W. C., et al. : Results of pharyngeal flap surgery in patients with velopharyngeal incompetence, Plast. Reconstr. Surg. $32: 493-501,1963$.

14) Owsley, J.Q. and Blackfield, H. M. : The technique and complications of pharyngeal flap surgery, Plast. Reconstr. Surg. 35:531-539, 1965.

15) Owsley, J.Q., Lawson, L.I., et al.: Experiences with the high attached pharyngeal flaps, Plast. Reconstr. Surg. $38: 232-242,1966$.

16) Isshiki, N., Honjow, I., et al. : Cineradiographic analysis of movement of the lateral pharyngeal wall, Plast. Reconstr. Surg. 44:357-363, 1969.

17) Padgett, E.C.: The repair of cleft palates after unsuccessful operations with special reference to cases with an extensive loss of palatal tissue, Arch. Surg. 20:453-472, 1930 .

18) Conway, H. and Goulian, D. Jr. : Experiences with the pharyngeal flap in cleft palate surgery, Plast. Reconstr. Surg. 26:590-595, 1960.

19) Padgett, E.C. and Stephenson, K. L., : Plastic and Reconstructive Surgery. Charles C. Thomas, Springfield Illinois, 1948. 
20 Fára, M., Sedláčková, E., et al. : Primary pharyngofixation in cleft repair, Plast. Reconstr. Surg. $45: 449--458,1970$.

21) Fára, M. : Increase of the biological value of the pharyngeal by tubation of its pedicle, Acta. Chir. Plast. 13:57-60, 1971.

22) Hynes, W. : Pharyngoplasty by muscle transplantation, Br. J. Plast. Surg. 3:128-135, 1950 .

23) Sullivan, D.E. : Bilateral pharyngoplasty as an aid to velophayngeal closure, Plast. Reconstr. Surg. $27: 31-39,1961$.

24）世良利次：種々の方法に䟣る口腔粘膜切開創の組織反忍ならびに治痖機転に関する実験的病理組織学的比較 研究 (其) 一) , 口病誌 $7: 309-319,1933$.

25）世良利次：種々の方法に依る口腔粘膜切開創の組織反心ならびに治療機転に関する実験的病理組織学的比較 研究 (其)二, 口病誌 $8: 23-41,1934$.

26）北村勝也・小田 晋・他：口唇裂術後性洀痕の神経組織学的研究，九州雨会誌 $21: 397-405,1968$.

27) 迫田隅男：舌の創傷治瘾に関する神経組織学的研究, 九州崠会誌 $30: 401-422,1976$.

28) 今井 環・橋本美智雄: 病理学, 医学畫院, 東京, 1973, 197-207.

29）小沢喜市：横紋筋の再生修復時江於ける細胞改築，信州医誌 $8: 1932-1956,1959$.

30）石井秀人：唇弁反転術における移植部の病理組織学的ならびに神経組織学的研究, 菌科学報 $71: 421 一$ $447,1971$.

31) Smith, R. R. and Dedo, H. H. : Innervation of the superior pharyngeal constrictor muscle, Ann. Otol. Rhinol. Laryngol. 80:92-96, 1971.

32 McCoy, F. J. and Zahorsky, C. L. : A new approach to the elusive dynamic pharyngeal flap, Plast. Reconstr. Surg. 49:160-164, 1972 .

33) Young, J. Z.: The functional repair of nervous tissue, Physiol Rev. 22:318-374, 1942 .

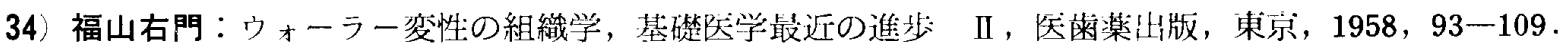

35)竹内一郎：神経組織の位相差顕微鏡的観察, 京府矤大誌 $60: 243-252,1956$.

36) 松下正義：末梢神経の切断による神経線維の変性及び再生に関する病理組織学的並びに電子顕微鏡的研究,

岡山医誌 $71: 8253-8270,1959$.

37）入学陽一：唇弁反転法における移植部の治瘾過程汇関する笑験的研究，九州菌会誌 $33: 281-301,1979$.

38）内藤一男：䔟植皮虐片に於ける神経要素の発生に就て，脳と神経 $2: 219-222,1950$.

39）山田 浩：皮䖉移植特にその知覚恢復に関する研究, 第 2 編 実験的研究, 中部日整外災外会誌 $3: 1025-$ 1036,1960 .

40）阿部成善：遊離粘膜移植における神経分布の消長に関する垁験的研究，九州霜会誌 $27: 653-674,1974$.

41) Santoni-Rugiu, P.: An experimental study on the reinnervation of free skin grafts and pedicle flaps, Plast. Reconstr. Surg. $38: 98-104,1966$.

42) Fára, M. and Véle, F.: The histology and electromyography of primary pharyngeal flaps, Cleft Plate J. $9: 319-324,1972$.

43) Smith, J. W. : The anatomical and physiologic acclimatization of tissue transplanted by the lip switch technique, Plast. Reconstr. Surg. 26:40-56, 1960.

44）加藤克之：Abbe-Estlander 手術に扔ける移植部の機能回復に関する研究, 歯科学報 $65: 91-121,1965$.

45）玉井国昭：Cross Lip Flap の筋電図学的考察, 形成外科 $13: 176-186,1970$. 


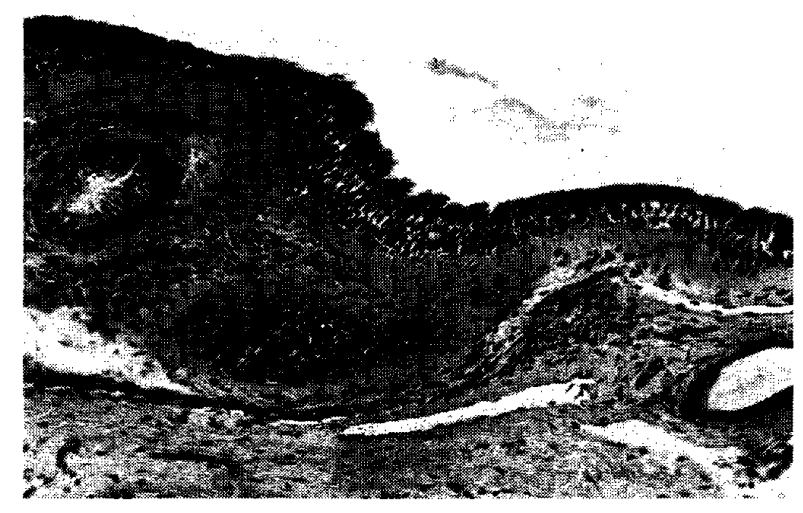

写 真 1

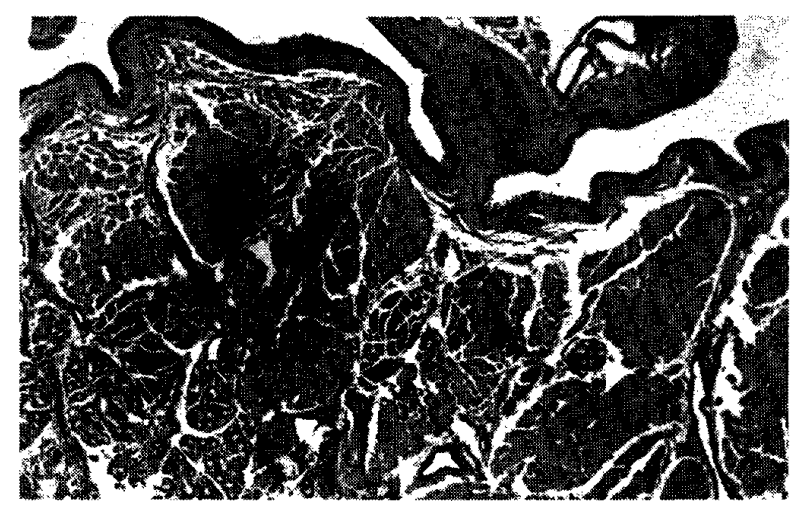

" $j$ 埧 2

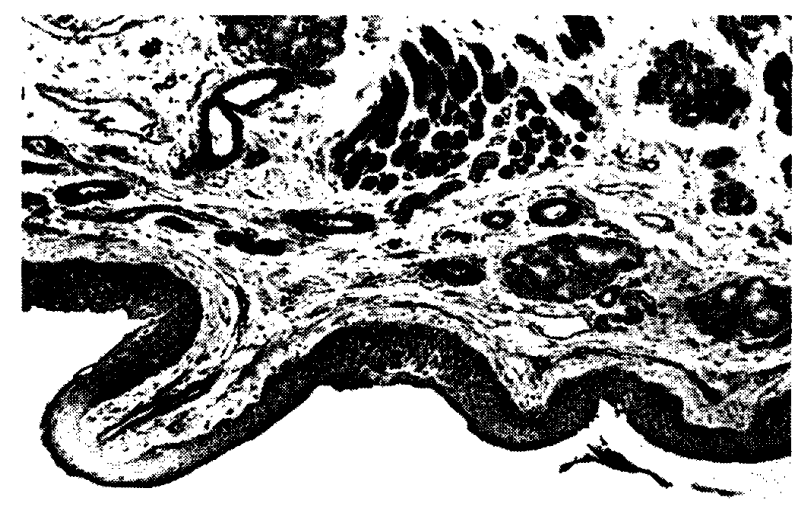

$$
\text { 与 真 } 3
$$

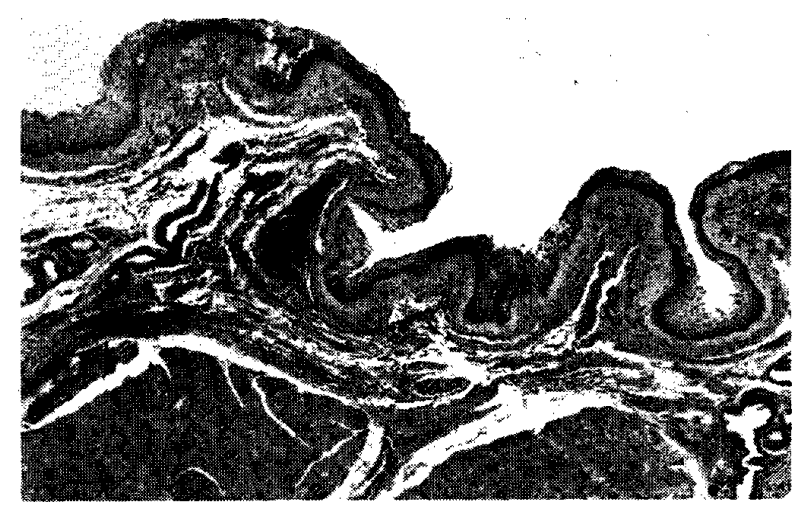

婙桌 4

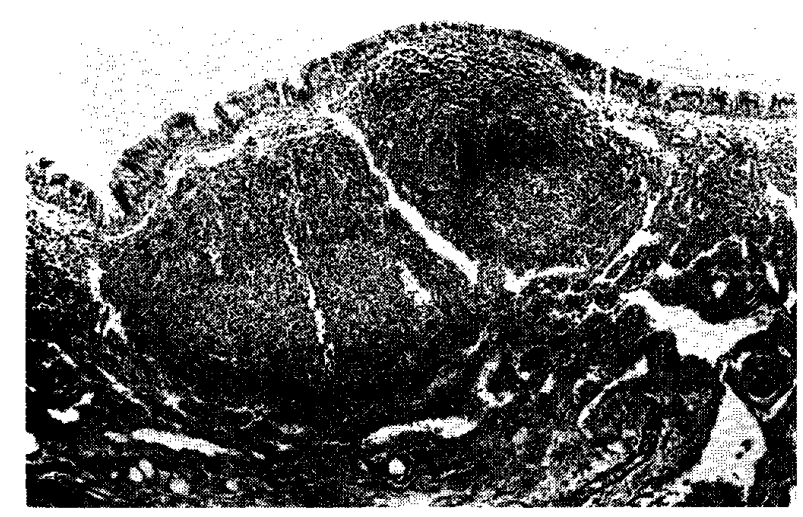

羊 頡 5

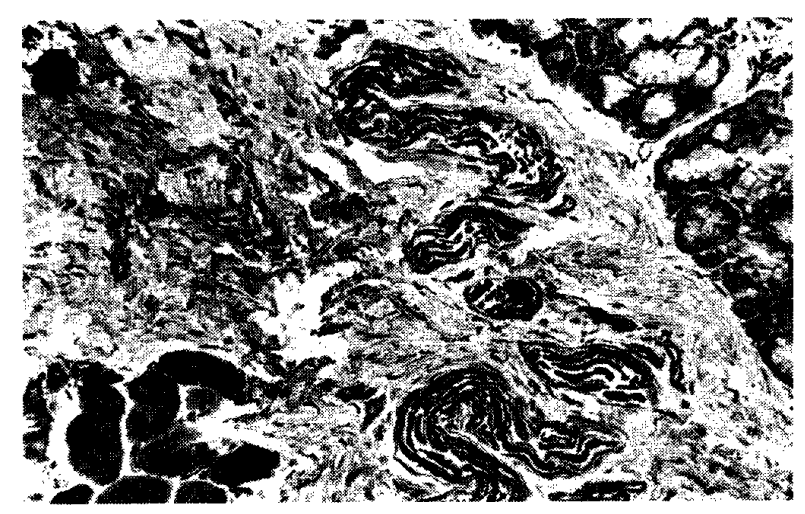

基 6

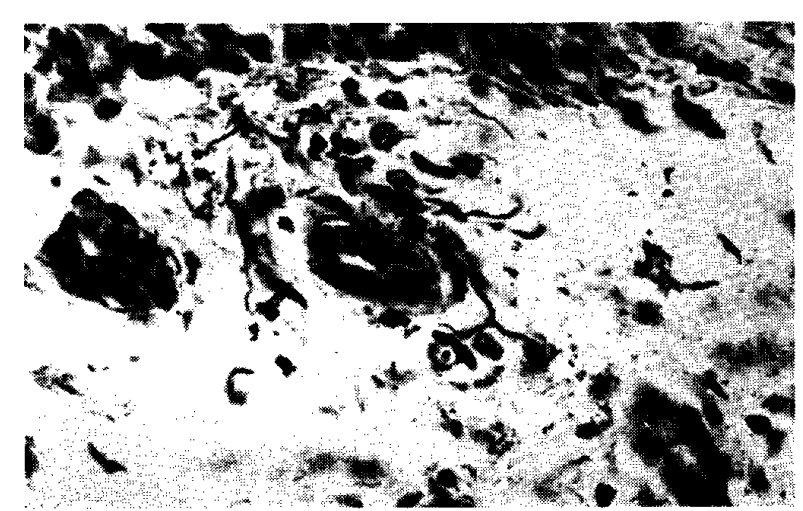

写 真 7

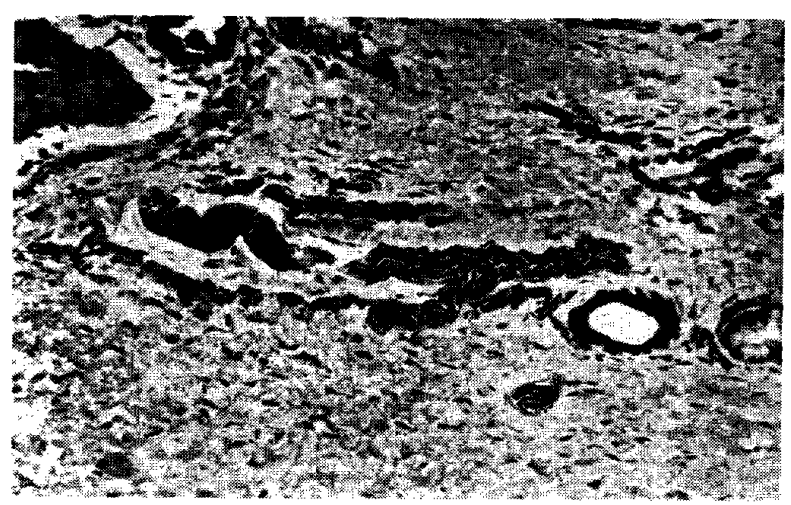

写 8 


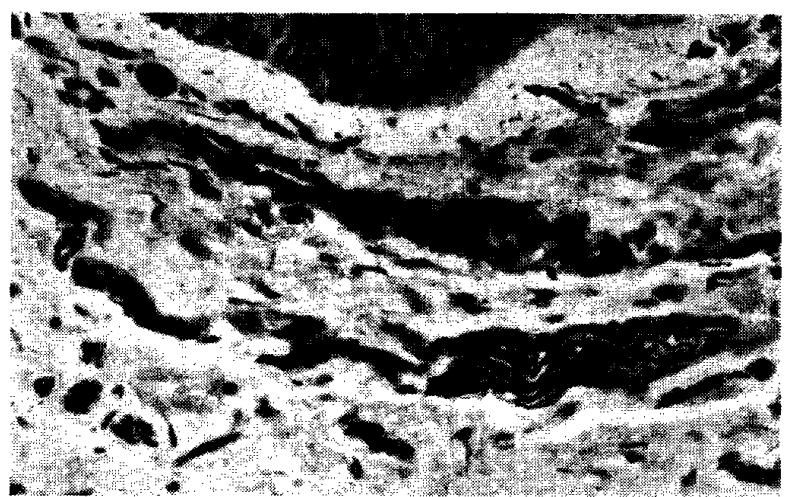

骂 真 9

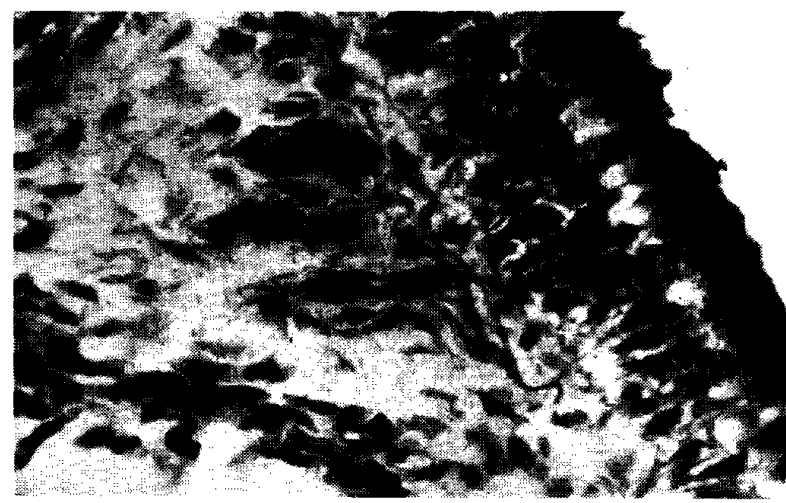

当 真 10

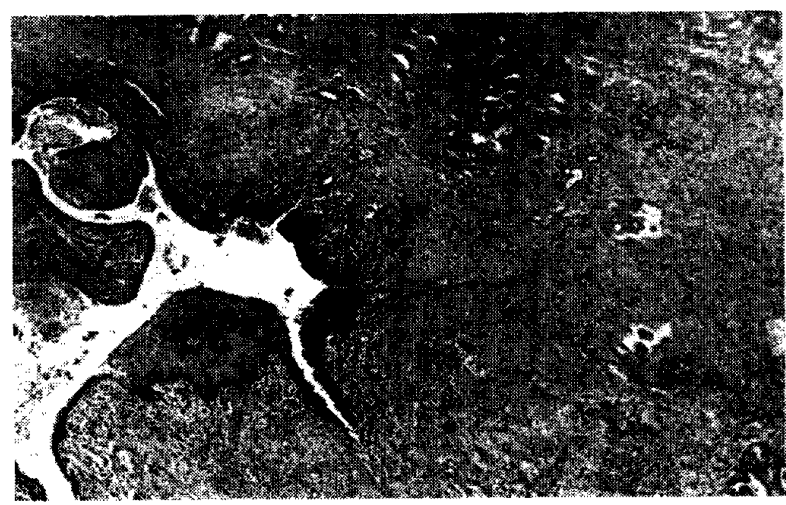

写 点 11

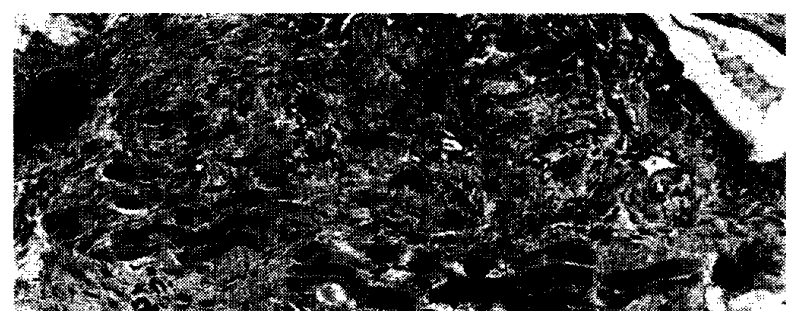

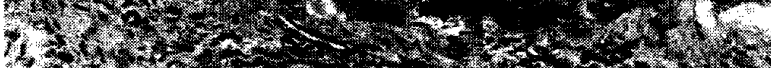

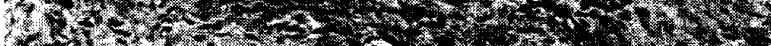

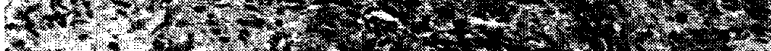

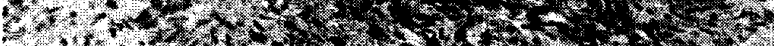

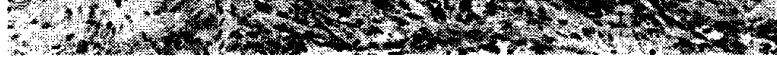
学 真 12

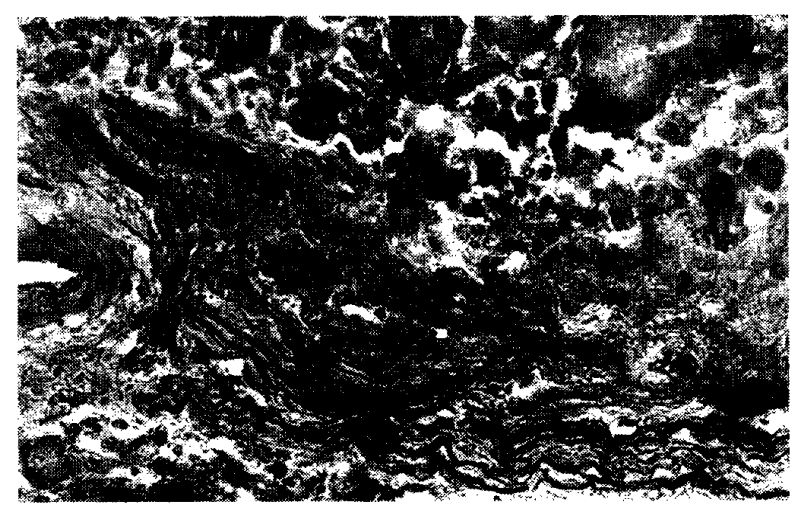

写 真 13

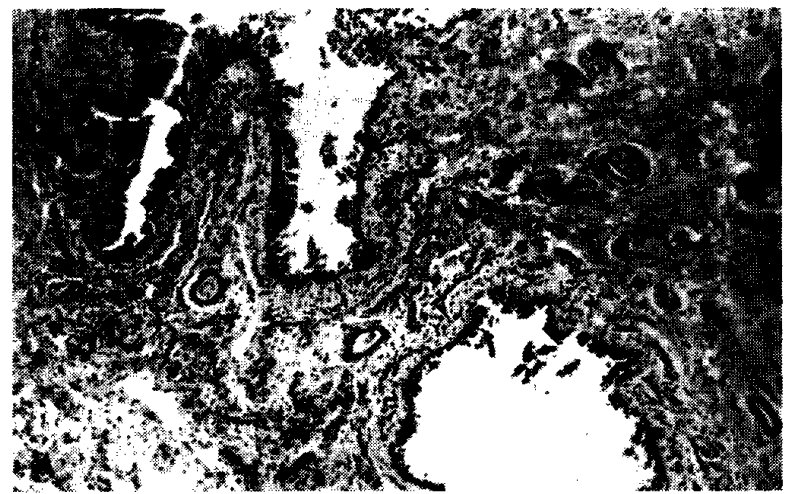

等 14

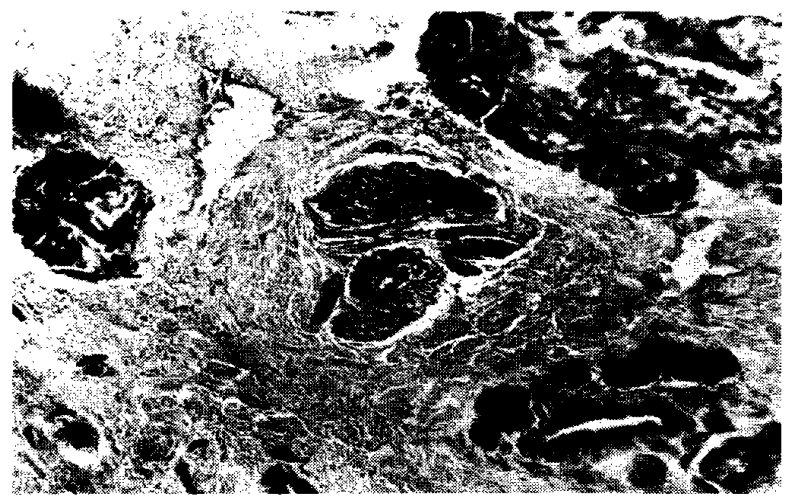

写 真 15

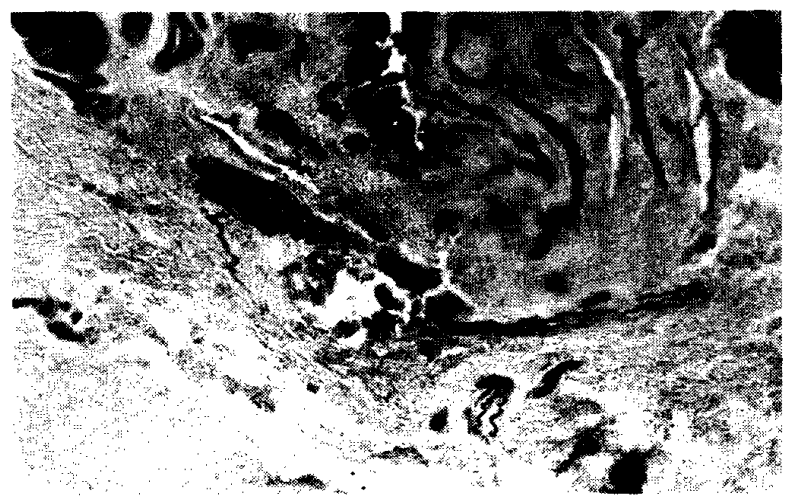

写 真 16 


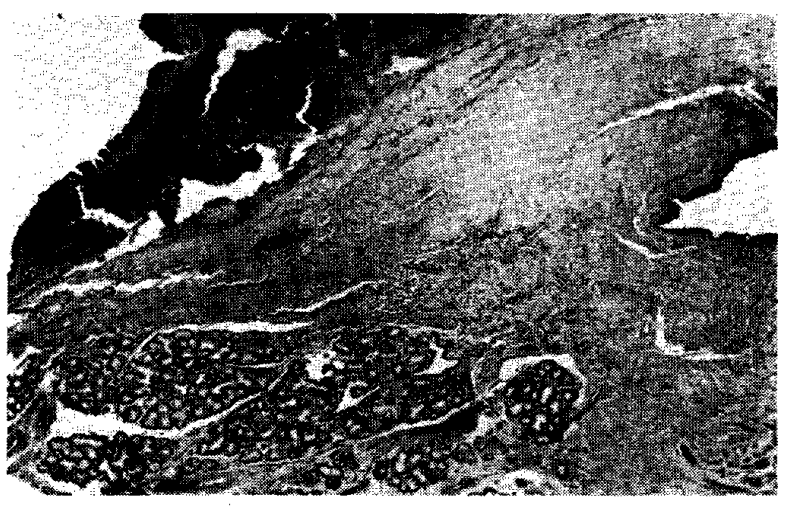

宁 真 17

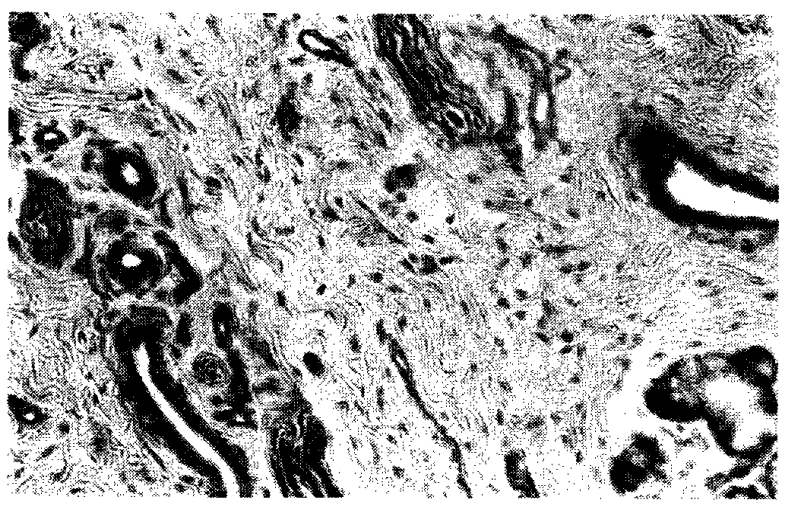

$$
\text { 证 It } 18
$$

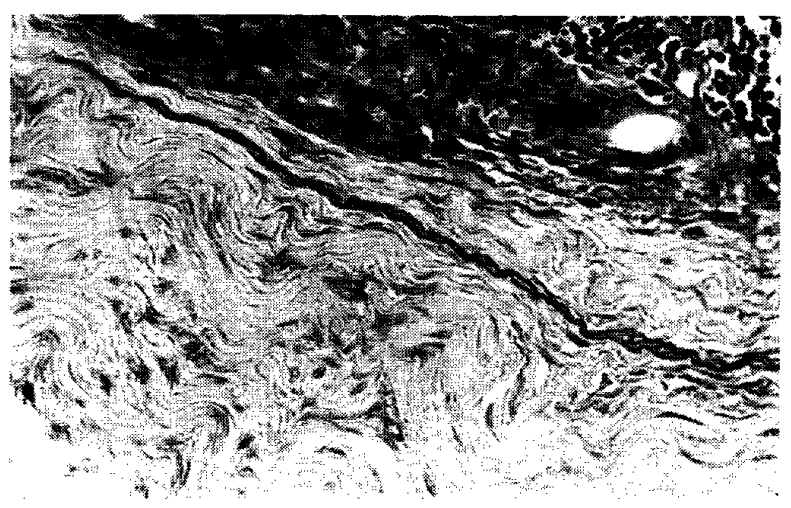

$$
\text { 评等 } 19
$$

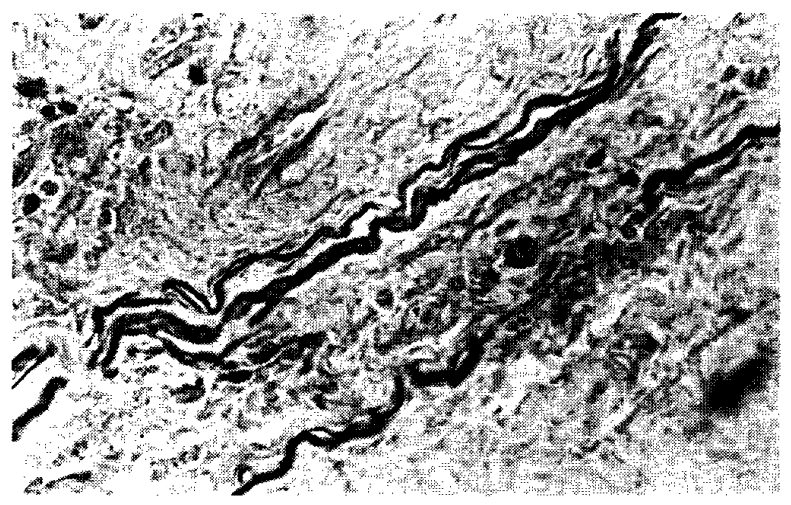

भ. 证 20

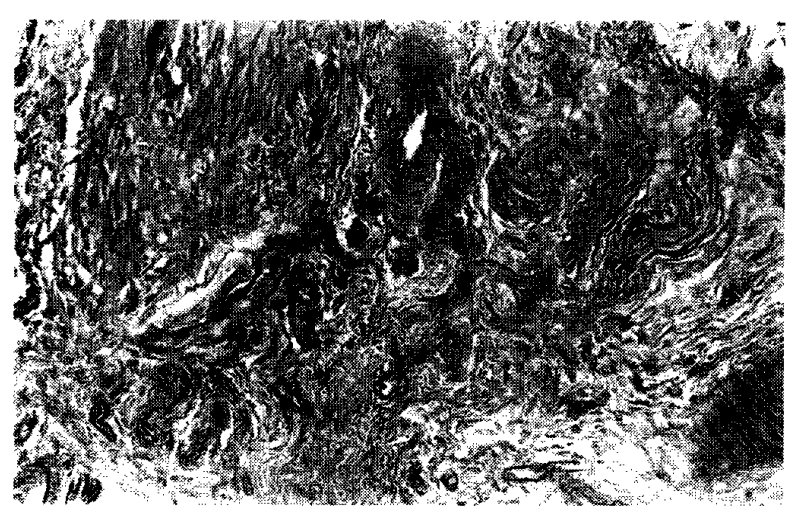

等 21
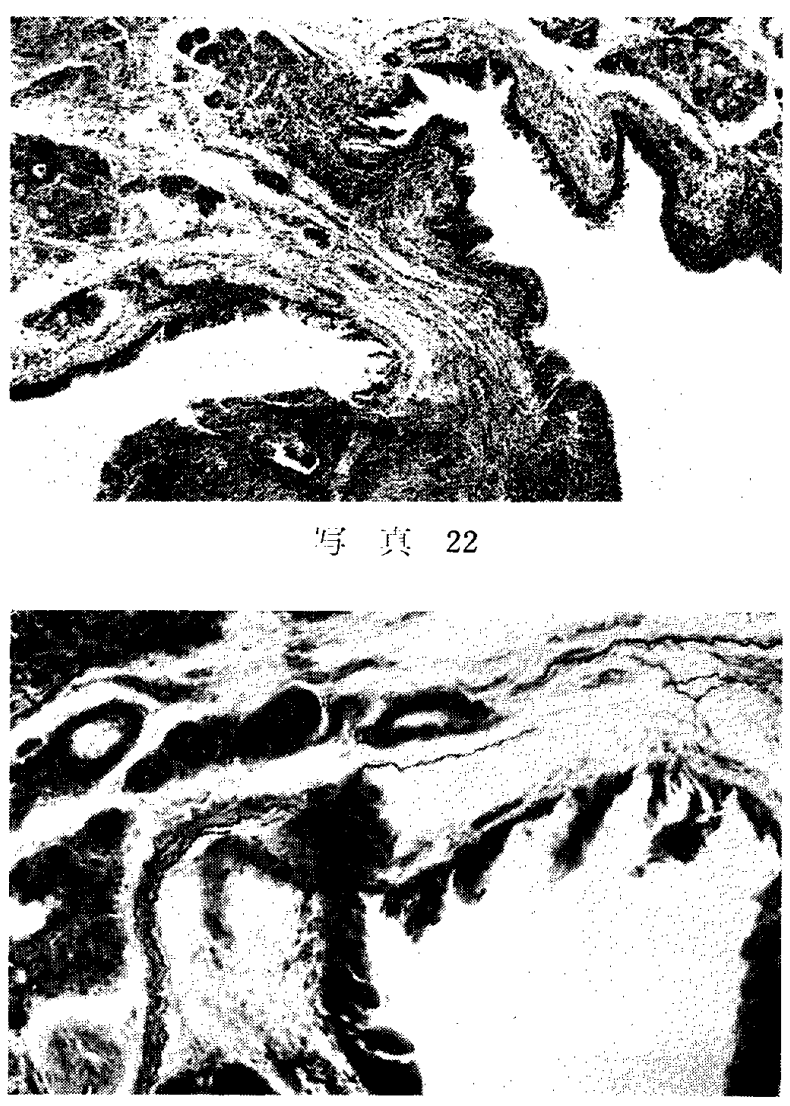

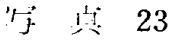

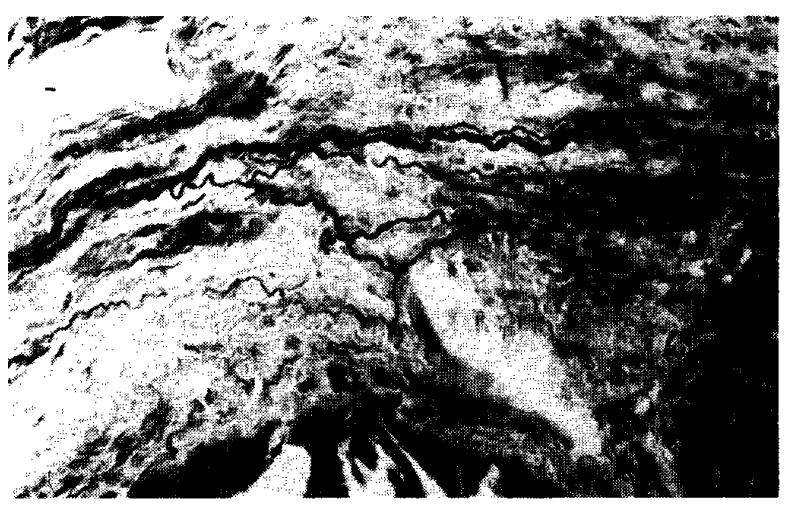

j. İ 24 


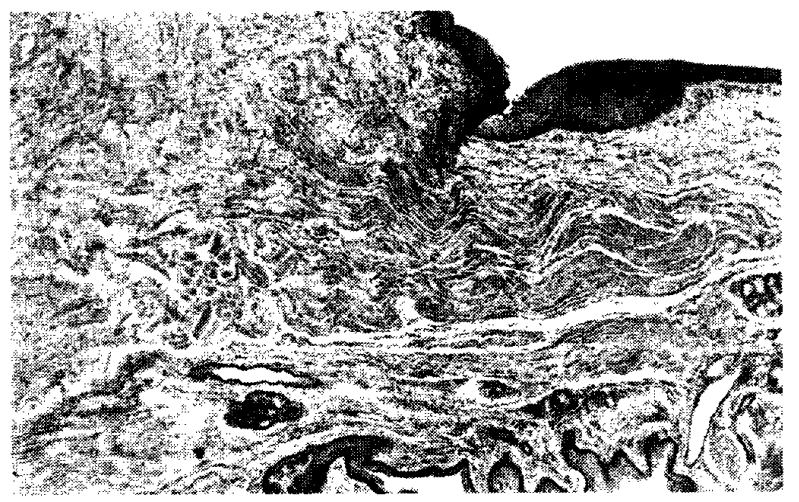

年: 趩 25

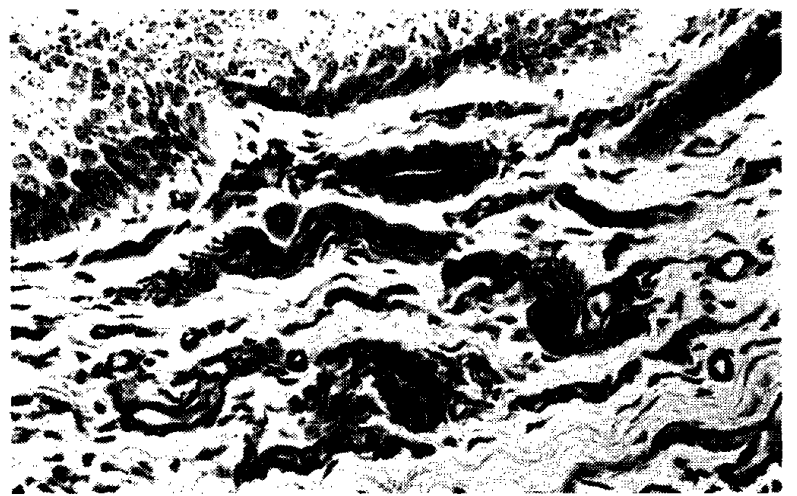

$$
\text { 婙 其 } 26
$$
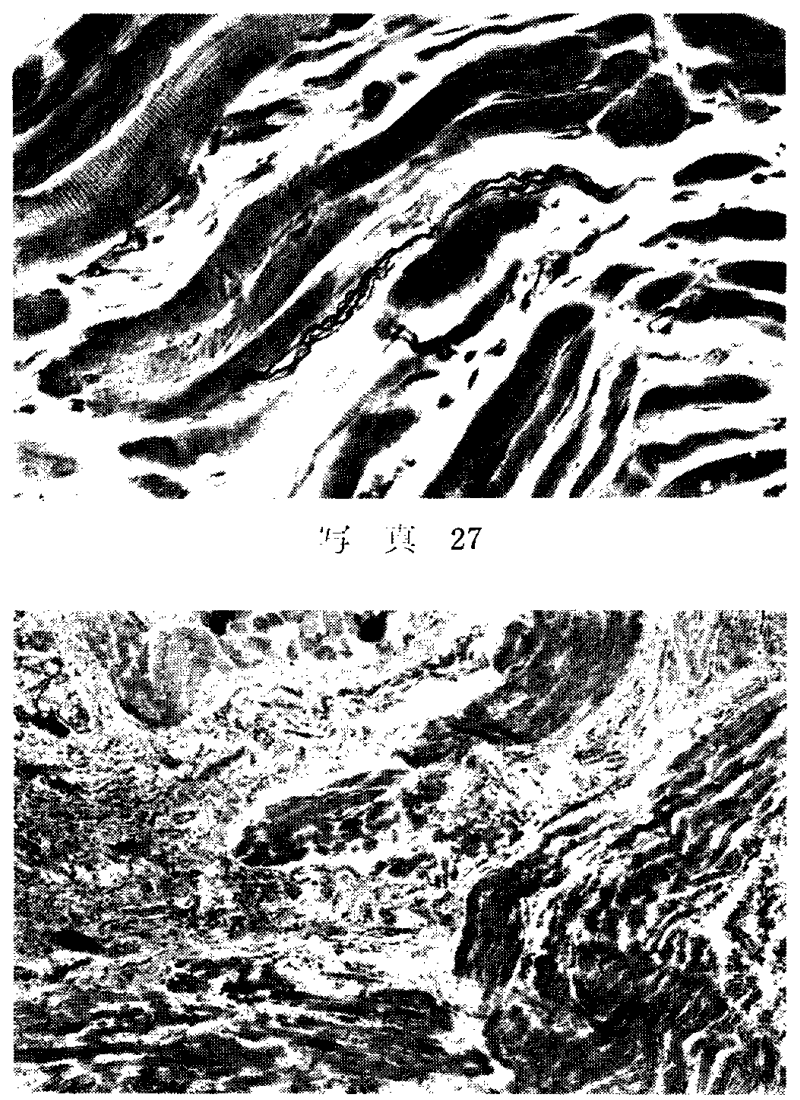

28
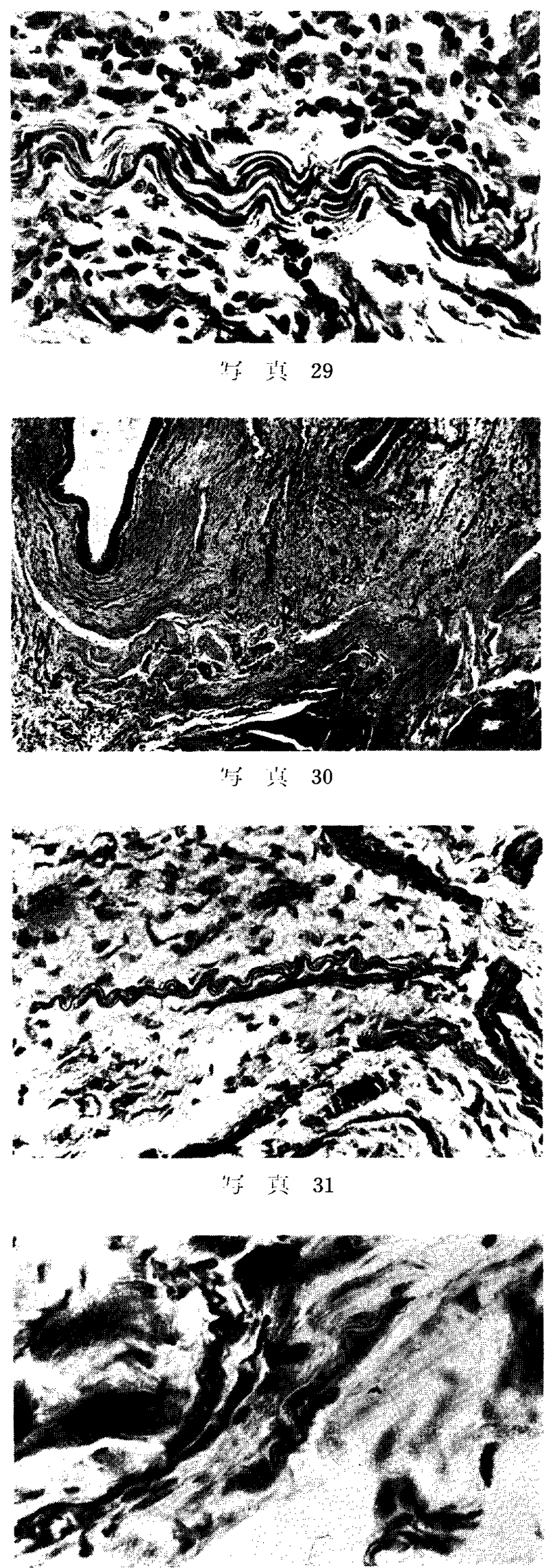